\title{
Epidemiology of HIV/AIDS in the East Azerbaijan Province, Northwest of Iran
}

\author{
Seyyed Mortaza Haghgoo ${ }^{1}$; Hadi Joula ${ }^{1}$; Ramin Mohammadzadeh ${ }^{1}$; Siamak Sabour ${ }^{2}$; Reza \\ Yousefi ${ }^{3}$; Gholamreza Ghahramani ${ }^{3}$; Ali A. R. Rahimi ${ }^{4}$, \\ ${ }^{1}$ Student Research Center, Tabriz University of Medical Sciences, Tabriz, IR Iran \\ ${ }^{2}$ Department of Clinical Epidemiology (COH), Shahid Beheshti University of Medical Sciences, Tehran, IR Iran \\ ${ }_{3}^{3}$ Health Center of East Azerbaijan Province, Tabriz University of Medical Sciences, Tabriz, IR Iran \\ ${ }^{4}$ Department of Medical Microbiology, Tabriz University of Medical Sciences, Tabriz, IR Iran \\ ${ }^{*}$ Corresponding author: Ali Rahimi, Department of Medical Microbiology, Tabriz University of Medical Sciences, Tabriz, IR Iran. Tel: +98-9127624297, Fax: +98-4113360510, \\ E-mail:ali.rahimi@alumni.uottawa.ca
}

Received: April 28, 2014; Revised: July 13, 2014; Accepted: July 25, 2014

\begin{abstract}
Background: This study was performed in response to the rapid propagation of HIV/AIDS across Iran and its status in this region. Accordingly, an evidence-based program is required to combat this disease.

Objectives: The present study estimated the prevalence of HIV|AIDS in East Azerbaijan (population:3,724,000).

Materials and Methods: We created a database of all positive cases from 1987 to 2012 . We also analyzed and described the epidemiological status of HIV|AIDS during a 25-year period by using SPSS.

Results: In East Azerbaijan, 371 HIV|AIDS cases have been reported, i.e. 1 case per 10,000 population. The vast majority of reported cases (91\%, $\mathrm{n}=338)$ were men, whereas only $9 \%(\mathrm{n}=33)$ were women. The mean age of patients was $30.8 \pm 12.3$ years. Unsafe drug injection $(59 \%, \mathrm{n}=219)$ and sexual interaction $(13 \%, \mathrm{n}=48)$ were the two major modes of HIV transmission. In addition, $7 \%(\mathrm{n}=25)$ of patients have been diagnosed with HIV, hepatitis B Virus, and hepatitis C virus simultaneously. Moreover, $60 \%(n=205)$ of men were infected via drug injection, while $82 \%$ $(\mathrm{n}=27)$ of women were infected via unprotected sexual interaction $(\mathrm{P}<0.001)$.

Conclusions: The results indicate a rapid increase in the number of HIV/AIDS cases in East Azerbaijan, necessitating immediate attention and strategies to combat the rapid spread of the disease. Development of provincial and national HIV|AIDS strategies demands more accurate and comprehensive HIV/AIDS surveillance.
\end{abstract}

Keywords: HIV; Acquired Immunodeficiency Syndrome; Epidemiology

\section{Background}

When the HIV epidemic peaked in 1993, AIDS was the leading cause of death among 25 - 44-year-old men and women and the eighth most common cause of death worldwide (1). Injection drug use (IDU) and unprotected sex are considered as major risk factors for the acquisition of retroviral infection (2-4), and more than half of people living with HIV are women and girls (2, 5-7). Because of social, economic, and political differences among regions, the epidemic has not been uniform $(8,9)$. The most common route of HIV transmission in high-income countries such as the United States and the United Kingdom is homosexuality. People who engage in high-risk sexual behaviors in Sub-Saharan Africa and IDUs in Eastern Europe and Southeast Asia are the major at-risk groups (10-14). In 2011, adolescents, women, homosexuals, and serodiscordant couples (i.e. one partner is HIV positive, and the other is HIV negative) were reported to be the populations with the highest risk of infection (10).

Although the AIDS epidemic is relatively mild in Asia, factors such as low condom use, unsafe injections among injection drug users, immigration, lack of education, and misconceptions about HIV/AIDS could affect the HIV/AIDS epidemic in all countries that currently have low prevalence (15-17). According to estimates by the Ministry of Health and Medical Education, as of September 21, 2011, approximately 23,500 people were living with HIV in Iran. More than $91 \%$ of these patients were men, and approximately 4,400 had died (18). Needle sharing in IDUs is the most common route of HIV transmission in men in Iran, accounting for approximately $70 \%$ of established transmissions. However, studies show an increased rate of high-risk behaviors for HIV infection, particularly unprotected sex (18-22). In addition, it is important to consider the HIV infection prevalence in specific populations in Iran, such as patients with tuberculosis (23).

Rapid changes in the epidemiological characteristics of infectious diseases necessitate health practitioners being aware of the current status of these diseases, espe-

Copyright (C) 2015, Ahvaz Jundishapur University of Medical Sciences. This is an open-access article distributed under the terms of the Creative Commons Attribution-NonCommercial 4.0 International License (http://creativecommons.org/licenses/by-nc/4.0/) which permits copy and redistribute the material just in noncommercial usages, provided the original work is properly cited. 
cially in cases of pandemic diseases such as AIDS, whose control requires global efforts (24-26). In this regard, research should serve as a tool to improve the effectiveness of healthcare systems. Successful AIDS prevention and treatment depend on the complete and accurate identification of at-risk populations as well as regular and standardized data collection, analysis, and interpretation (1, 27). One of the best opportunities to combat AIDS in Iran is the use of the healthcare system. However, behavioral research in the general population and high-risk groups is not systematic, integrated, or consistent $(24,28)$.

\section{Objectives}

The present study investigated the epidemiology of HIV/AIDS in East Azerbaijan, Iran.

\section{Patients and Methods}

This retrospective study was conducted during 1987-2012 in East Azerbaijan, Iran. The target population was all patients with HIV/AIDS in East Azerbaijan province, including patients who acquired HIV infection through IDU, sexual transmission, mother-to-child transmission (i.e. vertical transmission), and contaminated blood products. The Vice Chancellor of Research and Technology of Tabriz University of Medical Sciences ethical committee approval was obtained for the study (decision number: 5.4.328). First, necessary supplies including computers, telephone lines, etc. were prepared for project implementation. Data including age, sex, transmission route, etc. (Table 1) were extracted and entered into Microsoft Excel software for classification and sorting. Next, data were analyzed, and diagrams and tables were created using Microsoft Excel and SPSS. Quantitative variables are presented as mean \pm standard deviation (SD). The $\chi^{2}$ test was used to analyze qualitative variables. Meanwhile, regression analysis was used to evaluate the roles of confounding factors. The level of significance was set at $\mathrm{P}<0.05$.

\section{Results}

Among the 371 patients who were identified by healthcare centers in East Azerbaijan from 1987 to 2012 (Figure $1), 91 \%(n=338)$ were men and $9 \%(n=33$ cases $)$ were women. The prevalence of HIV/AIDS increased along with the population growth from 1987 to 2012 (data not shown), the current prevalence of HIV/AIDS in East Azerbaijan is $1 / 10,000$. The mean ages of the total, male, and female patients were $30.8 \pm 12.3,31.3 \pm 12.1$, and $28 \pm 10.3$ years, respectively. Moreover, $48 \%$ of the patients were 25 - 34 years old.

Most identified patients were from Tabriz $(n=228)$. Approximately $54 \%(n=200)$ of patients were single (Table 1). More than one-third $(\mathrm{n}=131)$ of patients had died, and $27 \%(n=99)$ were actively undergoing regular consultation (Figure 2). The most common transmission route was related to IDU $(59 \%, n=219)$ (Table 1$)$. The educational status of about $30 \%$ of patients $(n=112)$ was unknown. Among patients with known educational status, approxi- mately $80 \%(n=208)$ of them had high school or lower (Table 1$)$. The occupational status of $36 \%(n=102)$ and $17 \%$ ( $\mathrm{n}=48$ ) of patients was recorded as "self-employed" and "unemployed," respectively (Table 1). The rest of the patients were employed in various jobs (data not shown).

The frequencies of coinfection with hepatitis $C$ virus (HCV), hepatitis B virus (HBV), syphilis, and toxoplasmosis with respect to sex are shown in Table 2. Thirty-one of 207 patients (15\%) were diagnosed with HBV, and 25 of 371 patients were diagnosed with HIV/HBV/HCV co-infection.

Table 1. Demographic Characteristics of Patients With HIV|AIDS in East Azerbaijan, Iran From 1987 to 2012 a,b

\begin{tabular}{|c|c|}
\hline Characteristics & Values \\
\hline \multicolumn{2}{|l|}{ Sex } \\
\hline Male & $338(91)$ \\
\hline Female & $33(9)$ \\
\hline Total & $371(100)$ \\
\hline \multicolumn{2}{|l|}{ Age ,y } \\
\hline $0-20$ & $42(11)$ \\
\hline $20-40$ & $264(71)$ \\
\hline$\geq 40$ & $65(18)$ \\
\hline Total & $371(100)$ \\
\hline \multicolumn{2}{|l|}{ Education level } \\
\hline Illiterate & $37(10)$ \\
\hline $\begin{array}{l}\text { Primary and secondary } \\
\text { school }\end{array}$ & $214(58)$ \\
\hline University & $7(2)$ \\
\hline Unknown & $113(30)$ \\
\hline Total & $371(100)$ \\
\hline \multicolumn{2}{|l|}{ Marital status } \\
\hline Single & $200(54)$ \\
\hline Married & $122(33)$ \\
\hline Unknown & $49(13)$ \\
\hline Total & $371(100)$ \\
\hline \multicolumn{2}{|l|}{ Hometown } \\
\hline Tabriz & $228(61)$ \\
\hline Maragheh & $44(12)$ \\
\hline Myaneh & $26(7)$ \\
\hline Other & $57(15)$ \\
\hline Unknown & $16(5)$ \\
\hline Total & $371(100)$ \\
\hline \multicolumn{2}{|l|}{ Transmission route } \\
\hline IDU & $219(59)$ \\
\hline IDU and unprotected sex & $51(14)$ \\
\hline Unprotected sex & $42(11)$ \\
\hline Blood transfusion & $10(2.5)$ \\
\hline Vertical transmission & $3(0.8)$ \\
\hline $\begin{array}{l}\text { Unprotected sex and tat- } \\
\text { tooing }\end{array}$ & $3(0.8)$ \\
\hline IDU and blood transfusion & $1(0.3)$ \\
\hline Tattooing & $1(0.3)$ \\
\hline Needling & $1(0.3)$ \\
\hline Unknown & $40(11)$ \\
\hline Total & $371(100)$ \\
\hline
\end{tabular}

\footnotetext{
b IDU: injection drug use.
} 


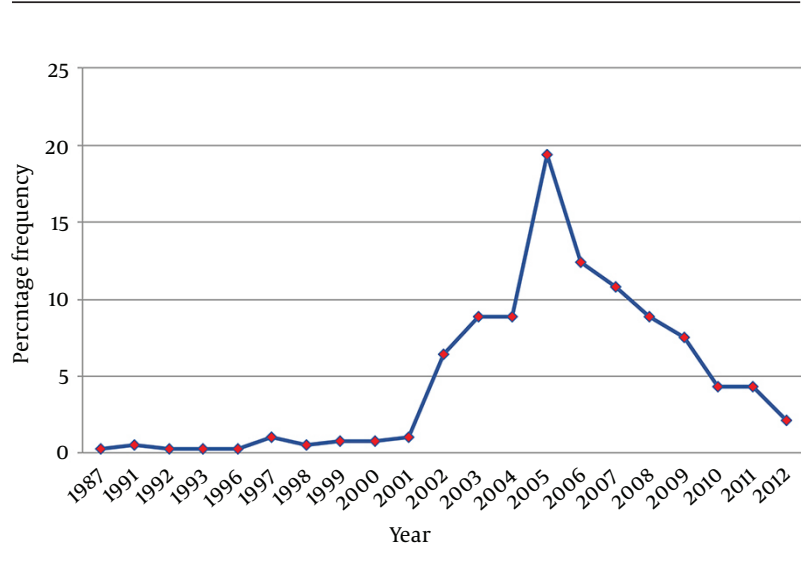

Figure 1. Percentage of frequency in Patients With HIV/AIDS in East Azerbaijan, Iran From 1987 to 2012
Figure 2. Current Status of Patients With HIV|AIDS Who Have Registered by Council Centers in East Azerbaijan

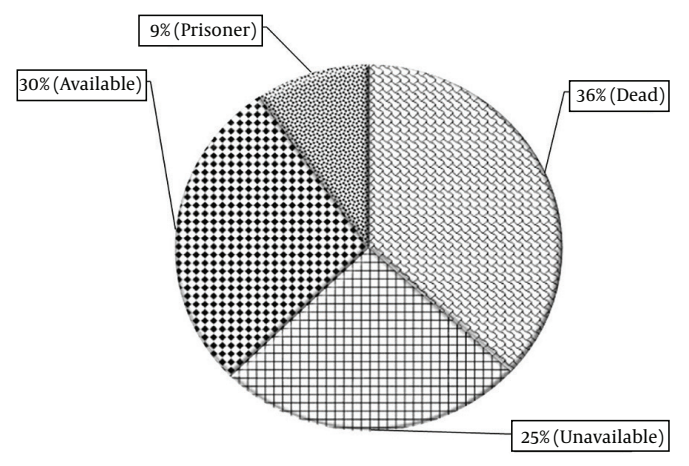

Available: patients who actively undergoing regular consultation; Unavailable: Patients who haven't referred to Council Centers since they have diagnosed as HIV positive.

Table 2. Frequencies of Coinfections in Patients with HIV/AIDS in East Azerbaijan, Iran From 1987 to 2012 a,b

\begin{tabular}{lcccc}
\hline Coinfection & Hepatitis B & Hepatitis C & Syphilis & Toxoplasmosis \\
\hline Test result & $\mathrm{P}: 31(8)$ & $\mathrm{P}: 168(45)$ & $\mathrm{P}: 3(1)$ & $\mathrm{P}: 94(25)$ \\
Test result & $\mathrm{N}: 176(48)$ & $\mathrm{N}: 42(12)$ & $\mathrm{N}: 107(29)$ & $\mathrm{N}: 63(17)$ \\
Test result & $\mathrm{UD}: 164(44)$ & $\mathrm{UD}: 161(43)$ & $\mathrm{UD}: 261(70)$ & UD: 214 (58) \\
Total & $371(100)$ & $371(100)$ & $371(100)$ & $371(100)$ \\
\hline
\end{tabular}

a Data are presented as No.(\%).

b P: positive, N: negative, UD: undetermined.

Table 3. HIV/AIDS Transmission Routes by Age Group in East Azerbaijan, Iran From 1987 to 2012 a,b

\begin{tabular}{lcccc}
\hline Transmission route & \multicolumn{3}{c}{ Age group $(\mathbf{y})$} & Total \\
\cline { 2 - 4 } & $\mathbf{0 - 1 9}$ & $\mathbf{2 0}-\mathbf{3 9}$ & $\mathbf{2 0}$ & $219(59.3)$ \\
\hline IDU & $11(3)$ & $166(44.9)$ & $42(11.4)$ & $51(13.8)$ \\
IDU and unprotected sex & 0 & $42(11.4)$ & $9(2.4)$ & $42(11.4)$ \\
Unprotected sex & $3(0.8)$ & $33(8.9)$ & $6(1.6)$ & $1(0.3)$ \\
IDU and blood transfusion & 0 & $1(0.3)$ & 0 & $58(15.3)$ \\
Other & $28(7.6)$ & $22(5.9)$ & $8(1.8)$ & $371(100)$ \\
\hline
\end{tabular}

a Data are presented as No. (\%).

b IDU: injection drug use.

\section{Discussion}

The HIV epidemic has entered the concentrated phase in Iran. The prevalence of HIV infection among injection drug users is reported to be $15.07 \%$ (18). The results of the present study show that IDU is the most common HIV transmission route in East Azerbaijan province, which is similar to national reports on HIV|AIDS (18). In a study conducted in Tehran and Kermanshah provinces, unsafe needle sharing was the reported cause of $83 \%$ of HIV infections (29). Another study performed in 2007 in Imam Khomeini Hospital in Tehran reports IDU as the most common HIV transmission route (31\%) (30). Furthermore, a study conducted by researchers at Shiraz University of
Medical Sciences reports $76 \%$ of patients had a history of IDU. However, in the present study, IDU was not the only route of HIV acquisition (31), 15\% of patients simultaneously had a history of IDU and other high-risk behaviors. A study conducted in China in 2008 found that the most common HIV transmission route is IDU ( $>43 \%$ of transmissions) (32). Meanwhile, a study in the US reports the most common HIV transmission route is homosexual contact in men, whereas IDU is ranked third (1). Thus, it seems that educating prisoners and injection drug users, reducing jail time, focusing on public education, making more efforts to provide methadone for people unable 
to quit their drug addiction, and doing research counseling methods and behavioral disorders at healthcare centers and prisons may improve the current status of the HIV epidemic (24,33-36). Many studies conducted in Iran report the prevalence of HIV/AIDS is higher in men than in women (approximately 85 - 95\% higher) (29, 31, 37, 38). However, the 2010 Joint United Nations Programme on HIV/AIDS Global Report states that more than $50 \%$ of people living with HIV worldwide are women and girls (39). The higher prevalence of HIV infection among men in Iran and East Azerbaijan could be due to a lack of precise data on the number of sex workers, which may partly explain the low rate of HIV/AIDS in women.

HBV and HCV coinfection among patients infected with HIV is common; and severe complications can occur in these patients (40). Severe complications can occur in patients with coinfection via the same transmission route of HIV (40-44). The present results show that $53 \%$ of patients with HIV/AIDS were coinfected with HCV, HBV, or both. In a study conducted in southwestern Iran, HCV or HBV coinfection was detected in $80 \%$ of patients infected with HIV (45). However, the prevalence of coinfection with hepatitis viruses in patients with HIV/AIDS varies among studies as well as populations with respect to exposure to different risk factors, geographic region, and ethnicity $(41,46)$.

One limitation of the present study is that the sample may not be representative of the total population in East Azerbaijan province. Furthermore, the paper-based records of some patients were incomplete, preventing us from analyzing some variables (associated to the clinical features) (e.g. some laboratory parameters). However, the present study is one of the few studies on this topic that have been conducted in Iran; there are no reports from many other provinces. The findings of this study highlight the information gap in this area and help fill in a small part of it. It is noteworthy that some countries have had success in controlling and preventing contagious diseases such as HIV through healthcare systems set up for the general population; thus, the development of effective methods on the basis of evidence and data is clearly possible $(22,24,28,47-50)$.

\section{Acknowledgements}

The authors would like to thank the Vice Chancellors of Research and Technology and Health of the Tabriz University of Medical Sciences, Health Center of East Azerbaijan as well as Dr. Ahmad Kousha, the head of the Health Center, for his contributions to the project.

\section{Authors' Contributions}

Study concept and design: Ali Rahimi; Acquisition of data: Seyyed Mortaza Haghgoo, Hadi Joula, Ramin Mohammadzadeh, Reza Yousefi, Gholamreza Ghahramani, Ali Rahimi; Data analysis and interpretation: Siamak Sabour, Seyyed Mortaza Haghgoo; Drafting of the manu- script: Seyyed Mortaza Haghgoo, Ali Rahimi; Critical revision of the manuscript for important intellectual content: Seyyed Mortaza Haghgoo, Siamak Sabour, Ali Rahimi; Statistical analysis: Siamak Sabour; Administrative, technical, and material support: Reza Yousefi, Gholamreza Ghahramani; Study supervision: Ali Rahimi.

\section{Funding/Support}

This research was supported by a grant (5/46/116) from the Vice Chancellor of Research of Tabriz University of Medical Sciences and the Student Research Center.

\section{References}

1. Hariri S, McKenna MT. Epidemiology of human immunodeficiency virus in the United States. Clin Microbiol Rev. 2007;20(3):478-88.

2. Joint United Nations Programme on HIV/AIDS (UNAIDS). UNAIDS report on the global AIDS epidemic 2013. 2013

3. Jenness SM, Neaigus A, Hagan H, Murrill CS, Wendel T. Heterosexual HIV and sexual partnerships between injection drug users and noninjection drug users. AIDS Patient Care STDS. 2010;24(3):175-81.

4. Centers for Disease Control Prevention. HIV prevalence estimates--United States, 2006. MMWR. Morbidity and mortality weekly report. 2008;57(39):1073.

5. Zhu BY, Bu J, Huang PY, Zhou ZG, Yin YP, Chen XS, et al. Epidemiology of sexually transmitted infections, HIV, and related high-risk behaviors among female sex workers in Guangxi Autonomous Region, China. Jpn JInfect Dis. 2012;65(1):75-8.

6. Quinn TC, Overbaugh J. HIV/AIDS in women: an expanding epidemic. Science. 2005;308(5728):1582-3.

7. Türmen T. Gender and HIV/aids. Int $J$ Gynecol Obstetrics. 2003;82(3):411-8.

8. Poundstone KE, Strathdee SA, Celentano DD. The social epidemiology of human immunodeficiency virus/acquired immunodeficiency syndrome. Epidemiol Rev. 2004;26:22-35.

9. Koopman JS, Longini Jr IM. The ecological effects of individual exposures and nonlinear disease dynamics in populations. Am J Public Health. 1994;84(5):836-42.

10. Buchbinder SP. HIV epidemiology and breakthroughs in prevention 30 years into the AIDS epidemic. Top Antivir Med. 2011;19(2):38-46.

11. Farr AC, Wilson DP. An HIV epidemic is ready to emerge in the Philippines. J Int AIDS Soc. 2010;13(1):16.

12. Weniger BG, Limpakarnjanarat K, Ungchusak K, Thanprasertsuk S, Choopanya K, Vanichseni S, et al. The epidemiology of HIV infection and AIDS in Thailand. Aids. 1991;5:71-86.

13. Bozicevic I, Voncina L, Zigrovic L, Munz M, Lazarus JV. HIV epidemics among men who have sex with men in central and eastern Europe. Sex Transm Infect. 2009;85(5):336-42.

14. Delpech VC, Yin Z, Abernethy J, Hill C, Logan L, Chadborn TR, et al. The impact in the UK of the Central and Eastern European HIV epidemics. Epidemiol Infect. 2009;137(9):1266-71.

15. Wood E, Montaner JSG, Chan K, Tyndall MW, Schechter MT, Bangsberg D, et al. Socioeconomic status, access to triple therapy, and survival from HIV-disease since 1996. Aids. 2002;16(15):2065-72.

16. Houweling TAJ, Kunst AE, Mackenbach JP. World Health Report 2000: inequality index and socioeconomic inequalities in mortality. Lancet. 2001;357(9269):1671-2.

17. Ghahfarokhi SM, Forouzan AS, Roshanfekr P, Mohammadi MA Dejman M, Vameghi M, et al. HIV/AIDS related knowledge and attitude among female sex workers in Tehran/Iran. Retrovirology. 2010;7(Suppl 1):P130.

18. (UNAIDS) JUNPoHA. Country progress reports (Islamic Republic of Iran Report). 2012

19. Fallahzadeh H, Morowatisharifabad M, Ehrampoosh MH. HIV/ AIDS epidemic features and trends in Iran, 1986-2006. AIDS Behav. 2009;13(2):297-302.

20. Alavi SM, Shushtari MHS. HIV/AIDS Among Injecting Drug Users: 
A review on Epidemiology and Management of Occupational Exposure in Iranian Health Network Setting. Jundishapur J Microbiol. 2013;6(8)

21. Rahbar AR, Rooholamini S, Khoshnood K. Prevalence of HIV infection and other blood-borne infections in incarcerated and non-incarcerated injection drug users (IDUs) in Mashhad, Iran. Int J Drug Policy. 20 04;15(2):151-5.

22. Haghdoost AA, Mostafavi E, Mirzazadeh A, Navadeh S, Feizzadeh A, Fahimfar N, et al. Modelling of HIV/AIDS in Iran up to 2014. J AIDS HIV Res. 2011;3(12):231-9.

23. Alavi SM, Moradzadegan H, Khoshkhoy MM. Seroprevalence of HIV in Newly Detected Pulmonary Tuberculosis Patients in Khuzestan, Iran: Should HIV testing be included in National Tuberculosis Program in this Region. Jundishapur J Microbiol. 2013;6(2):193-6.

24. Haghdoost A, Sadeghi M, Nasirian M, Mirzazadeh A, Navadeh S. Research priorities in the field of HIV and AIDS in Iran.J Res Med Sci. 2012;17(5):481-6.

25. Folkers GK, Fauci AS. Controlling and ultimately ending the HIV/ AIDS pandemic: a feasible goal. JAMA. 2010;304(3):350-1.

26. Jones DA. Encyclopedia of Microbiology. Oxford: Academic Press; 2009. AIDS, Historica.

27. Centers for Disease Control, Prevention. Racial/ethnic disparities in diagnoses of HIV/AIDS-33 states, 2001-2004. MMWR. Morbidity and mortality weekly report. 2006;55(5):121.

28. World Health Orgnization. Guidelines for planning serosurveillance of HIV (Prevalence of sexually transmitted infections and the behavioural components of second generation surveillance of HIV). 2005

29. Zali MR, Mehr AJ, Rezaian M, Meamar AR, Vaziri S, Mohraz M. Prevalence of intestinal parasitic pathogens among HIV-positive individuals in Iran. Jpn J Infect Dis. 2004;57(6):268-70

30. Rahimi M. Epidemiology and risk factors of 377 AIDS (HIV infected) patients. Medical Science Journal of Islamic Azad UnivesityTehran Medical Branch. 2007;17(2):103-6.

31. Bagheri P, Faramarzi H, Sabet M. The Survey of Risk Factors in HIV Positive Patients Covered by Shiraz University of Medical Sciences. J Isfahan Med School. 2011;29(157)

32. Sheng L, Cao WK. HIV/AIDS epidemiology and prevention in China. Chinese Med J. 2008;121(13):1230-6.

33. Sajadi L, Mirzazadeh A, Navadeh S, Osooli M, Khajehkazemi R, Gouya MM, et al. HIV prevalence and related risk behaviours among female sex workers in Iran: results of the national biobehavioural survey, 2010. Sex Transm Infect. 2013;89 Suppl 3:iii37-40.

34. Navadeh S, Mirzazadeh A, Gouya MM, Farnia M, Alasvand R, Haghdoost AA. HIV prevalence and related risk behaviours among prisoners in Iran: results of the national biobehavioural survey, 2009. Sex Transm Infect. 2013;89 Suppl 3:iii33-6.

35. Amirkhanian YA. Review of HIV vulnerability and condom use in central and eastern Europe. Sex Health. 2012;9(1):34-43.

36. Dolan K, Kite B, Black E, Aceijas C, Stimson GV. HIV in prison in low-income and middle-income countries. Lancet Infect Dis. 2007;7(1):32-41.

37. Moradi F, Nabaei B, Yeganeh B. The epidemiology of AIDS in Iran from beginning until now. Tehran Univ Med J. 2000;58(4):79-88.

38. Falahi SH, Badparva E, Nahravanian H, Mohammadi MA, Chang S, Ebrahimzadeh F. Comparison of the Prevalence of Intestinal Parasites in HIV-Positive and AIDS Patients in Khorramabad City in 2006-2007. J Kerman Univ Med Sci. 2009;16 (2):166-72.

39. Joint United Nations Programme on HIV/AIDS (UNAIDS). UNAIDS Report on the Global AIDS Epidemic 2010. 2010

40. Koziel MJ, Peters MG. Viral hepatitis in HIV infection. N Engl J Med. 2007;356(14):1445-54.

41. Alter MJ. Epidemiology of viral hepatitis and HIV co-infection.J Hepatol. 2006;44(1 Suppl):S6-9.

42. Sulkowski MS. Viral hepatitis and HIV coinfection. J Hepatol. 2008;48(2):353-67.

43. Weber R, Sabin CA, Friis-Moller N, Reiss P, El-Sadr WM, Kirk $\mathrm{O}$, et al. Liver-related deaths in persons infected with the human immunodeficiency virus: the D:A:D study. Arch Intern Med. 2006;166(15):1632-41.

44. Sulkowski MS, Thomas DL, Chaisson RE, Moore RD. Hepatotoxicity associated with antiretroviral therapy in adults infected with human immunodeficiency virus and the role of hepatitis $\mathrm{C}$ or B virus infection. JAMA. 2000;283(1):74-80.

45. Alavi SM. Relative frequency of infections among hospitalized injecting drug user-HIV positive patients in Razi hospital, Ahvaz, SW Iran (2001-2003). Jundishapur J Microbiol. 2008;2008(1, Winter):6-9.

46. Alberti A, Clumeck N, Collins S, Gerlich W, Lundgren J, Palu G, et al. Short statement of the first European Consensus Conference on the treatment of chronic hepatitis B and C in HIV co-infected patients. J Hepatol. 2005;42(5):615-24.

47. Motamedi-Heravi MM. HIV/AIDS Epidemiology. HIV/AIDS Diagnosis, Care and Treatment.Tehran: Seda Publication Center; 2003.

48. Pomerantz RJ, Horn DL. Twenty years of therapy for HIV-1 infection. Nat Med. 2003;9(7):867-73.

49. Nematollahi M, Hatam N. Designing a Regional Information System for Surveillance of Voluntary HIV/AIDS Counseling and Testing in Iran. Director General. 2011;8(4)

50. Karon JM, Fleming PL, Steketee RW, De Cock KM. HIV in the United States at the turn of the century: an epidemic in transition. Am J Public Health. 2001;91(7):1060-8. 